medRxiv preprint doi: https://doi.org/10.1101/2020.02.16.20023010; this version posted February 20, 2020. The copyright holder for this preprint (which was not certified by peer review) is the author/funder, who has granted medRxiv a license to display the preprint in It is made available under a CC-BY 4.0 International license .

\title{
A factorial Mendelian randomization study to systematically prioritize genetic targets for the treatment of cardiovascular disease
}

Genevieve M. Leyden, BSc${ }^{1,2}$, Tom R. Gaunt, $\mathrm{PhD}^{1}$, Tom G. Richardson, $\mathrm{PhD}^{1 *}$

${ }^{1}$ MRC Integrative Epidemiology Unit, University of Bristol

${ }^{2}$ Bristol Medical School: Translational Health Sciences, University of Bristol

*Corresponding author: Dr. Tom G. Richardson, MRC Integrative Epidemiology Unit, Bristol

Medical School (Population Health Sciences), University of Bristol

Address for correspondence:

Dr Tom G. Richardson

MRC Integrative Epidemiology Unit

University of Bristol

Oakfield House

Oakfield Grove

Bristol BS8 2BN

United Kingdom

Tom.G.Richardson@bristol.ac.uk

Total word count: $\mathbf{2 , 9 8 7}$ 
medRxiv preprint doi: https://doi.org/10.1101/2020.02.16.20023010; this version posted February 20, 2020. The copyright holder for this preprint (which was not certified by peer review) is the author/funder, who has granted medRxiv a license to display the preprint in It is made available under a CC-BY 4.0 International license .

\section{Key points}

Question Can naturally occurring genetic variation in a population help us highlight and prioritize novel therapeutic targets for the treatment of cardiovascular disease?

Findings In this factorial Mendelian randomization study of 334,915 individuals, we found that a genetically predicted $0.09 \mathrm{mmol} / \mathrm{L}$ decrease in LDL cholesterol attributed to statin inhibition results in $4.1 \%$ lower risk of cardiovascular disease. We then highlighted various genetic targets which were genetically predicted to further reduce disease risk without evidence of adverse side effects, such as PRKCE which is involved in the development of cardiac hypertrophy and reduced risk of cardiovascular disease by $6.4 \%$ in addition to statin therapy.

Meaning Evidence from genetic analyses can improve the likelihood of success for therapeutic targets and findings from this study have prioritized several promising candidates for the treatment of cardiovascular disease. 
medRxiv preprint doi: https://doi.org/10.1101/2020.02.16.20023010; this version posted February 20, 2020. The copyright holder for this preprint (which was not certified by peer review) is the author/funder, who has granted medRxiv a license to display the preprint in perpetuity.

It is made available under a CC-BY 4.0 International license .

Abstract

Importance New drugs which provide benefit alongside statin mono-therapy are warranted to reduce risk of cardiovascular disease.

Objective To systematically evaluate the genetically predicted effects of 8,851 genes and cardiovascular disease risk factors using data from the UK Biobank and subsequently prioritize their potential to reduce cardiovascular disease in addition to statin therapy.

Design, Setting, and Participants A factorial Mendelian randomization study using individual level data from the UK Biobank study. This population-based cohort includes a total of 502,602 individuals aged between 40 and 96 years old at baseline who were recruited between 2006 to 2010 .

Exposures Genetic variants robustly associated with the expression of target genes in whole blood (based on $\mathrm{P}<5 \times 10^{-08}$ ) were used to construct gene scores using findings from the eQTLGen consortium $(n=31,684)$.

Main Outcomes and Measures Genetically predicted effects for each of the 8,851 genes were firstly evaluated with 5 measured outcomes from the UK Biobank in turn (body mass index, diastolic blood pressure, systolic blood pressure, low-density lipoproteins and triglycerides). Effects surviving multiple comparisons from this initial analysis were subsequently analyzed using factorial Mendelian randomization to evaluate evidence of an additive beneficial effect on cardiovascular disease risk compared to a $H M G C R$ genetic score acting as a proxy for statin inhibition. Finally, a phenome-wide analysis was undertaken to evaluate predicted effects between prioritized targets and 569 outcomes in the UK Biobank to highlight potential adverse side-effects.

Results 377 genetically predicted effects on cardiovascular disease risk factors were identified by Mendelian randomization (based on $\mathrm{P}<1.13 \times 10^{-6}$ ). Of the 68 druggable genes, 20 candidate genes were predicted to lower cardiovascular disease risk in combination with statin treatment $\left(\mathrm{P}<7.35 \times 10^{-4}\right)$. Genes such as FDFT1 were predicted to have added benefit with statin therapy $\left(\mathrm{OR}=0.93 ; 95 \% \mathrm{CI}, 0.91-0.95 ; \mathrm{P}=2.21 \times 10^{-10}\right)$ but are unlikely to make safe targets due to their predicted effects on adverse side effects. In contrast, PRKCE provided evidence of a putative added benefit in combination with statins $\left(\mathrm{OR}=0.94 ; \mathrm{CI}, 0.91-0.96 ; \mathrm{P}=1.72 \times 10^{-9}\right)$ with no predicted adverse effects.

Conclusions and Relevance Through the application of a systematic factorial Mendelian randomization analysis, we have prioritized (and deprioritized) potential drug targets predicted to reduce cardiovascular disease risk in addition to statin therapy. 
medRxiv preprint doi: https://doi.org/10.1101/2020.02.16.20023010; this version posted February 20, 2020. The copyright holder for this preprint (which was not certified by peer review) is the author/funder, who has granted medRxiv a license to display the preprint in It is made available under a CC-BY 4.0 International license.

\section{Keywords}

Mendelian randomization, factorial study design, drug validation, phenome-wide association study, UK Biobank, 
medRxiv preprint doi: https://doi.org/10.1101/2020.02.16.20023010; this version posted February 20, 2020. The copyright holder for this preprint (which was not certified by peer review) is the author/funder, who has granted medRxiv a license to display the preprint in It is made available under a CC-BY 4.0 International license.

\section{Abbreviations}

CVD - Cardiovascular disease

RCT - Randomized control trial

MR - Mendelian Randomization

GWAS - Genome wide association study

eQTL - expression quantitative loci

UKB - UK Biobank

PheWAS - Phenome wide association study

SNP - Single nucleotide polymorphism

BMI - Body mass index

DBP - Diastolic blood pressure

SBP - Systolic blood pressure

LDL - Low-density lipoproteins

TG - Triglycerides

IVW - Inverse variance weighted

GRS - Genetic risk score 
medRxiv preprint doi: https://doi.org/10.1101/2020.02.16.20023010; this version posted February 20, 2020. The copyright holder for this preprint (which was not certified by peer review) is the author/funder, who has granted medRxiv a license to display the preprint in perpetuity.

It is made available under a CC-BY 4.0 International license.

\section{Introduction}

Cardiovascular disease (CVD) is an increasingly prevalent public health concern and remains the leading cause of death worldwide ${ }^{1}$. Cholesterol lowering drugs such as statins (3hydroxy-3-methylglutaryl coenzyme A reductase [HMGCR]-inhibitors) are regarded as the gold-standard treatment option in terms of lowering the risk of CVD including myocardial infarction and stroke ${ }^{2,3}$. Whilst the effectiveness of statins in risk reduction for both primary and secondary CVD has been established in randomized control trials (RCTs) ${ }^{4,5}$, they have also been reported to have adverse side-effects in certain patients, such as an increased risk of developing type- 2 diabetes ${ }^{6}$ and weight-gain ${ }^{7}$. Furthermore, there is major unmet clinical need for the identification of additional drugs to achieve adequately lower CVD risk in patients undergoing statin mono-therapy ${ }^{8}$ or a viable alternative to it ${ }^{9}$.

Mendelian Randomization (MR) is a technique in causal inference which uses naturally occurring genetic variation to investigate the relationship between modifiable exposures (such as the anticipated effect of a drug) and disease outcomes ${ }^{10,11}$. By exploiting the random assortment of genetic alleles at birth, MR is often considered analogous to the allocation of individuals to drug and placebo groups in an RCT, without the concerns of non-adherence ${ }^{12}$. As such, findings from MR are less prone to confounding and reverse causation which can hinder classical observational studies.

Recent studies have demonstrated the value of conducting genetic and MR analyses to mimic the putative effects of therapeutic intervention ${ }^{13-15}$. Multiple studies have examined the relative relationship between lifelong genetic inhibition of $H M G C R$ and alternative genetic targets ${ }^{16,17}$. These studies have used a $2 \times 2$ factorial approach, which stratifies the sample population by allelic risk scores to estimate the separate and combined effects of genetic proxies of therapeutic intervention on CVD outcomes. Such developments have established 
medRxiv preprint doi: https://doi.org/10.1101/2020.02.16.20023010; this version posted February 20, 2020. The copyright holder for this preprint (which was not certified by peer review) is the author/funder, who has granted medRxiv a license to display the preprint in It is made available under a CC-BY 4.0 International license .

MR as a powerful approach for drug discovery and improved understanding of disease aetiology.

In this study, we describe an MR framework designed to systematically prioritize putative genetic targets which are predicted to have an independent and additive benefit alongside statin treatment. This approach was applied to evaluate genetically predicted effects of 8,851 genetic targets on measures of CVD risk in the UK Biobank study (UKB) ${ }^{18}$. Genes identified in this analysis were subsequently analyzed using $2 \times 2$ factorial to assess whether therapeutically targeting them may have a predicted reduced risk on CVD in addition to statin therapy. Finally, we performed a phenome-wide association study (PheWAS) to highlight any putative adverse effects for prioritized targets identified in the previous analyses. In doing so, we demonstrate the ability of this framework to capture diverse biological functions and recapitulate results outlined in preclinical studies, strengthening the validity of this approach to prioritize (and deprioritize) drug targets for therapeutic validation. 
medRxiv preprint doi: https://doi.org/10.1101/2020.02.16.20023010; this version posted February 20, 2020. The copyright holder for this preprint (which was not certified by peer review) is the author/funder, who has granted medRxiv a license to display the preprint in It is made available under a CC-BY 4.0 International license.

\section{Methods}

\section{Study populations and outcomes}

Single nucleotide polymorphisms (SNPs) robustly associated with changes to gene expression (i.e. $\mathrm{P}<5 \times 10^{-08}$ ) were selected as instrumental variables using findings from the eQTLGen consortium $(n=31,684){ }^{19}$. Our inclusion criterion was based on genes whose expression could be instrumented by at least 2 independent SNPs within a $1 \mathrm{Mb}$ distance of a gene's transcription start site (known as cis-eQTL). This was to improve the robustness of findings in line with the assumptions of MR, further details of which can be found in supplementary methods. A reference panel of European individuals from the 1000 genome project (phase 3) was used to identify independent SNPs based on $\mathrm{r}^{2}<0.01{ }^{20}$.

The UK Biobank is a prospective cohort study with detailed genotype and phenotype data on up to 500,000 participants ${ }^{18}$. The CVD risk factors we evaluated in our initial analysis using data from UKB were; body-mass index (BMI), diastolic blood pressure (DBP), systolic blood pressure (SBP), low-density lipoproteins (LDL) and triglycerides (TG). A derived outcome encompassing all CVD outcomes from UKB using data from field 20002 (such as coronary heart disease, hypertension and hypercholesterolemia) was used in the factorial $2 \times 2$ MR analysis. Individuals were therefore categorized as a case in our derived variable if they were a case for any CVD outcomes in this field. The phenome-wide analysis used data on 569 outcomes from UKB as described previously ${ }^{21}$, a full list of which can be found in Supplementary Table 11.

\section{Statistical analysis}

Identifying associations between genetically predicted gene expression and risk factors for cardiovascular disease 
medRxiv preprint doi: https://doi.org/10.1101/2020.02.16.20023010; this version posted February 20, 2020. The copyright holder for this preprint (which was not certified by peer review) is the author/funder, who has granted medRxiv a license to display the preprint in perpetuity.

It is made available under a CC-BY 4.0 International license .

To assess whether changes in gene expression have a putative causal role in CVD risk, cis-eQTL were harnessed as instrumental variables in a 2-sample MR analysis ${ }^{22}$. We applied the inverse variance weighted method (IVW) ${ }^{23}$ to estimate the effect of genetically predicted gene expression on each of the 5 CVD traits in turn using the 'TwoSampleMR' package ${ }^{24}$. Genetically predicted effects which survived multiple testing (based on $\mathrm{P}<0.05 /$ (number of genes analyzed*number of traits)) were subsequently filtered to identify those which were candidates for therapeutic intervention and therefore carried forward to downstream analyses. Targets were also filtered to identify those which were "druggable" using a comprehensive list of genes collated from recent data-driven drug-discovery and target selection strategies ${ }^{25-28}$.

\section{Systematic factorial Mendelian randomization analysis to prioritize therapeutic targets}

Individual-level genetic data was used from participants in UKB to construct genetic risk scores (GRS) for each 'druggable' gene associated with any of the 5 traits from the previous analysis. GRS were constructed as the sum of the effect alleles for eQTL SNPs weighted by their eQTLGen regression coefficients. To account for multiple testing in the factorial analysis, the genetically predicted effect between each GRS and CVD in UKB (based on data from field 20002 as described above) was estimated by using logistic regression with adjustment for age, sex and the first 10 principal components (PC) of ancestry. Only genes whose predicted effect on the derived CVD outcome (based on a multiple testing correction of $\mathrm{P}<0.05 /$ number of GRS evaluated) were analyzed in the factorial MR analysis. A previously published $H M G C R$ score was constructed using 6 LDL-associated variants within $100 \mathrm{~kb}$ of this gene to mimic the CVD lowering effect on statin therapy ${ }^{16}$.

We applied $2 \times 2$ factorial MR to systematically compare the effect of each gene associated with CVD in the previous analysis after accounting for the effect of the $H M G C R$ score. The UKB dataset consisting of 334,915 individuals (described in further detail in the 
medRxiv preprint doi: https://doi.org/10.1101/2020.02.16.20023010; this version posted February 20, 2020. The copyright holder for this preprint (which was not certified by peer review) is the author/funder, who has granted medRxiv a license to display the preprint in It is made available under a CC-BY 4.0 International license.

supplementary methods) was first dichotomized into halves based on the median of the $H M G C R$ score, and then into quarters based on the median of the potential novel gene target's GRS. The group consisting of individuals with below median values for both the $H M G C R$ and novel gene scores was subsequently used as the baseline group in further analyses. Each of the other groups were analyzed in turn with the baseline group to estimate the effect of genetically predicted effects for statin inhibition, new drug effect and a combined therapy. A graphical illustration of this approach can be found in Figure 1. Analyses involved logistic regression on the CVD outcome adjusting for the same covariates as before.

Phenome-wide association study (PheWAS)

Finally, we undertook a PheWAS analysis for each GRS prioritized in the previous analyses to highlight any potentially unanticipated adverse effects of therapeutic intervention. This was undertaken by evaluating the association between each GRS and 569 outcomes from the UKB. Continuous, binary and categorical traits were analyzed using linear, logistic and ordinal/multinomial logistic regression respectively. All analyses were adjusted for age, sex and the top 10 PCs. All analyses were undertaken using R (version 3.5.1) and all plots were created using the package 'ggplot2'. 
medRxiv preprint doi: https://doi.org/10.1101/2020.02.16.20023010; this version posted February 20, 2020. The copyright holder for this preprint (which was not certified by peer review) is the author/funder, who has granted medRxiv a license to display the preprint in perpetuity.

It is made available under a CC-BY 4.0 International license .

\section{Results}

\section{A systematic Mendelian Randomization analysis to identify novel candidate genes associated with cardiovascular disease}

The putative causal effect between the genetically predicted expression of 8,851 genes (Supplementary Table 1) and 5 cardiovascular disease traits in UKB (BMI, SBP, DBP, LDL and TG) was systematically screened in 44,255 distinct MR analyses. Overall, 377 genetically predicted effects were identified which survived the Bonferroni corrected threshold (Bonferroni $\mathrm{P}<0.05 / 44,255=1.13 \times 10^{-6}$ ) (Figure 2, Supplementary Table 2-6). A flow diagram summarizing downstream findings in this study can be found in Figure 3.

Leveraging multiple SNPs in an MR analysis may provide additional power to detect associations that may previously have been overlooked by conventional single SNP analyses. Filtering for genes whose individual SNP instruments would not have survived genome-wide corrections (i.e. $\mathrm{P}>5 \times 10^{-8}$ ), yet their combined IVW estimates resulted in an effect which would have $\left(\mathrm{P}<5 \times 10^{-8}\right)$, indicated that 67 of these association signals $(17.8 \%)$ would potentially have been missed by conventional single SNP analyses (Supplementary Table 7). For example, the association between FADSI and triglycerides would have been identified in a GWAS based on the strongest individual SNP effect for this gene $\left(\mathrm{P}=5.5 \times 10^{-109}\right)$. However, the association between POM121C would have been overlooked by conventional single SNP analyses (lowest individual $\mathrm{P}=9.40 \times 10^{-5}$ ), yet the combined effect of all eQTL provided stronger evidence of association (IVW $\mathrm{P}=5.83 \times 10^{-13}$ ). $P O M 121 C$ encodes a nucleoporin whose expression may be involved in regulating insulin sensitivity and adipogenesis ${ }^{29}$.

There were 68 candidate genes of the 377 putative effects that were "druggable", as defined by recent data-driven drug-discovery and target selection strategies 25-28 (Supplementary Table 8). Of these, there was strong evidence of a genetically predicted effect 
medRxiv preprint doi: https://doi.org/10.1101/2020.02.16.20023010; this version posted February 20, 2020. The copyright holder for this preprint (which was not certified by peer review) is the author/funder, who has granted medRxiv a license to display the preprint in It is made available under a CC-BY 4.0 International license.

between the expression of 20 genes and the CVD outcome in UKB based on our GRS analysis (Bonferroni $\left.\mathrm{P}=0.05 / 68=7.35 \times 10^{-4}\right)$.

\section{Prioritizing cardiovascular genes for therapeutic intervention using factorial Mendelian}

\section{randomization}

Next, we sought to discern whether there was genetic evidence of an additive CVD risk lowering effect of the 20 identified candidate genes compared to an $H M G C R$ score acting as a proxy for statin inhibition (Supplementary Table 9). The $H M G C R$ score was strongly associated with LDL cholesterol $\left(\right.$ Beta $\left.=-0.09, \mathrm{SE}=0.004, \mathrm{P}=5.88 \times 10^{-115}\right)$ and $\mathrm{CVD}(\mathrm{OR}=0.96$, $95 \% \mathrm{CI}=0.95-0.97, \mathrm{P}=8.81 \times 10^{-05}$ ) in the UK Biobank study. This suggests that each 0.09 $\mathrm{mmol} / \mathrm{L}$ decrease in LDL cholesterol attributed to statin inhibition results in $4.1 \%$ lower risk of CVD based on these estimates.

A summary of existing compounds for these genetic targets and their indications is provided in Supplementary Table 10. The genes with the largest magnitude of an additive effect included FDFT1, which encodes squalene synthase (SQS), a protein downstream HMGCR on the cholesterol biosynthesis pathway ${ }^{30}$. Individuals in the FDFT1-HMGCR "combined" lowrisk group were predicted to have lower odds of developing CVD (OR=0.93 per standard deviation increase in GRS; 95\% CI, 0.91-0.95; $\mathrm{P}=2.21 \times 10^{-10}$ ) than the "statin" group $(\mathrm{OR}=0.97 ; \mathrm{CI}, 0.95-0.99 ; \mathrm{P}=0.0053)$ (Figure 4). Similarly lower CVD risk estimates were predicted for the NEGR 1 combined effect with statins ( $\left.\mathrm{OR}=0.93 ; \mathrm{CI}, 0.91-0.95 ; \mathrm{P}=2.80 \times 10^{-11}\right)$ than the statin only group $(\mathrm{OR}=0.97 ; \mathrm{CI}, 0.95-0.99 ; \mathrm{P}=0.0068)$, and for $P R K C E$-combined $\left(\mathrm{OR}=0.94 ; \mathrm{CI}, 0.91-0.96 ; \mathrm{P}=1.72 \times 10^{-9}\right)$ vs statin only $(\mathrm{OR}=0.965 ; \mathrm{CI}, 0.94-0.99 ; \mathrm{P}=0.0014)$. In comparison, genes such as $S L C 5 A 11$ were associated with a more modest decreased risk of CVD in the "combined" $\left(\mathrm{OR}=0.94 ; \mathrm{CI}, 0.92-0.97 ; \mathrm{P}=1.13 \times 10^{-7}\right)$ than the "statin"-group $\left(\mathrm{OR}=0.96 ; \mathrm{CI}, 0.94-0.98 ; \mathrm{P}=8.52 \times 10^{-5}\right)$ (Figure 4). These analyses therefore suggest that the 
medRxiv preprint doi: https://doi.org/10.1101/2020.02.16.20023010; this version posted February 20, 2020. The copyright holder for this preprint (which was not certified by peer review) is the author/funder, who has granted medRxiv a license to display the preprint in perpetuity.

It is made available under a CC-BY 4.0 International license .

benefit of combined therapy (i.e. statins + new drug) for these novel gene targets would result in a reduction of between $6-7 \%$ reduction in CVD risk over the placebo group.

\section{Exploring phenome-wide associations to predict putative side effects of genetically}

\section{targeted therapeutics}

As a proof of concept, we firstly undertook a PheWAS to evaluate the genetically predicted effects of $H M G C R$ using the score used in the previous analysis (Figure 5A, Supplementary Table 12). The results predict that $H M G C R$ is associated with increased cholesterol $(\beta=0.038$ per standard deviation increase in GRS; 95\% CI, 0.035-0.041; $\left.\mathrm{P}=1.36 \times 10^{-106}\right)$ and LDL cholesterol $\left(\beta=0.040 ; \mathrm{CI}, 0.036-0.043 ; \mathrm{P}=7.92 \times 10^{-113}\right)$. As such, inhibiting $H M G C R$ will have a predictively beneficial lowering effect on these traits which is the anticipated outcome of statins. For example, statin use has been reported to increase risk of type-2 diabetes which is likely reflected in the PheWAS results which identified an association with increased glycated haemoglobin $(\mathrm{HbA1c})\left(\beta=-0.008 ; \mathrm{CI},-0.012--0.004 ; \mathrm{P}=4.10 \times 10^{-6}\right)$, a diagnostic marker of type-2 diabetes.

Full results from the PheWAS analyses for each of the 20 genes taken forward from the previous analysis can be found in Supplementary Tables 13-32). As expected, the PheWAS results for prioritized genes indicated an enrichment for traits with known roles in mediating CVD risk, in addition to novel secondary effects which may raise concern for the development of compounds targeting multiple pathways. For instance, FDFT1 and NEGRI were associated with 55 and 50 traits respectively (Bonferroni $\mathrm{P}=0.05 / 569=8.79 \times 10^{-5}$ ) (Figure 5B, Supplementary Figure 1A; Supplementary Table $19 \& 27)$. In addition to CVD related outcomes, there were also genetically predicted effects which may foreshadow adverse effects. For example, FDFT1 expression was associated with alkaline phosphatase $(\beta=0.022 ; \mathrm{CI}, 0.018$ - 0.022; $\left.\mathrm{P}=1.41 \times 10^{-35}\right)$ and alanine aminotransferase $\left(\beta=0.010 ; \mathrm{CI}, 0.006-0.013 ; \mathrm{P}=1.05 \times 10^{-}\right.$ 
medRxiv preprint doi: https://doi.org/10.1101/2020.02.16.20023010; this version posted February 20, 2020. The copyright holder for this preprint (which was not certified by peer review) is the author/funder, who has granted medRxiv a license to display the preprint in It is made available under a CC-BY 4.0 International license.

${ }^{08}$ ) which are markers of liver disease ${ }^{31}$. There was also evidence that NEGRl expression associates with fluid intelligence score $\left(\beta=0.026\right.$; $\left.\mathrm{CI}, 0.014-0.039 ; \mathrm{P}=3.69 \times 10^{-5}\right)$ in the same direction to anthropometric traits, suggesting that inhibiting NEGRl may have deleterious consequences on this trait.

In contrast, findings from the PheWAS analysis suggested that alternative targets may provide more viable therapeutic opportunities for genes such as SLC5A11 and PRKCE (Figure 5C, Supplementary figure 1B, Supplementary Tables $28 \& 30)$. SLC5A11 was associated with anthropometric traits such as BMI $\left(\beta=-0.01 ; \mathrm{CI},-0.013--0.007 ; \mathrm{P}=3.82 \times 10^{-9}\right)$, as well as cardiovascular traits including $\operatorname{SBP}\left(\beta=-0.012 ; \mathrm{CI},-0.015--0.008 ; \mathrm{P}=1.63 \times 10^{-12}\right) . P R K C E$ was more specifically associated with cardiovascular traits influencing blood pressure traits such as $\operatorname{SBP}\left(\beta=0.008 ; C I, 0.005-0.011 ; \mathrm{P}=1.99 \times 10^{-6}\right)$ and $\mathrm{DBP}\left(\beta=0.007 ; \mathrm{CI}, 0.004-0.01 ; \mathrm{P}=2.83 \times 10^{-}\right.$ ${ }^{5}$ ). Notably, there were no associations which provided strong evidence of potentially adverse secondary effects in this analysis for either gene. 
medRxiv preprint doi: https://doi.org/10.1101/2020.02.16.20023010; this version posted February 20, 2020. The copyright holder for this preprint (which was not certified by peer review) is the author/funder, who has granted medRxiv a license to display the preprint in perpetuity.

It is made available under a CC-BY 4.0 International license.

\section{Discussion}

In this study we present a comprehensive analytical pipeline which harnesses Mendelian randomization to assess whether the inhibition of novel drug targets may further reduce risk of cardiovascular disease in addition to statin treatment. Applying this framework in the UK Biobank study prioritized 20 genetic targets which were predicted to provide additional therapeutic benefit in combination with statins, including known cooperative drug interactions ${ }^{32}$. Exploring the putative effects of these targets on 569 outcomes supported the validity of this methodology at estimating potential secondary drug effects. For example, the HMGCR score was strongly associated with $\mathrm{HbA1C}$ in the opposite direction to LDL cholesterol, which is indicative of the increased risk of type 2 diabetes which may accompany statin therapy based on clinical evidence ${ }^{33}$. This approach was subsequently applied to each of the 20 identified genes detected to further prioritize their potential as a therapeutic target.

The use of large-scale genotype-phenotype datasets is becoming increasingly important as an early drug-development tool for informed target validation ${ }^{34}$. Our two-sample MR analysis using genetic instruments which influenced the expression of genetic targets identified 377 putative effects across 5 CVD risk factors. Amongst these findings were several candidate genes that have been evaluated previously in pre-clinical and clinical studies. This includes FDFT1 which encodes squalene synthase (SQS), a protein downstream HMGCR on the cholesterol biosynthesis pathway ${ }^{30}$. The therapeutic potential of SQS-inhibition has been explored in preclinical studies demonstrating cooperation between SQS-inhibitors and statins in achieving increased LDL-cholesterol clearance ${ }^{35}$. Despite our findings supporting the efficacy of FDFT1, there was also evidence of putative adverse side-effects. This included genetically predicted effects on alkaline phosphatase and alanine aminotransferase which suggests that this targets' protein product may have downstream consequences for liver 
medRxiv preprint doi: https://doi.org/10.1101/2020.02.16.20023010; this version posted February 20, 2020. The copyright holder for this preprint (which was not certified by peer review) is the author/funder, who has granted medRxiv a license to display the preprint in perpetuity.

It is made available under a CC-BY 4.0 International license .

function. SQS-inhibitors have been developed to late-stage clinical trial but have been discontinued due to treatment associated hepatotoxicity ${ }^{36}$.

Similarly, while the factorial MR analyses provided evidence that NEGRl may be an effective therapeutic target in lowering CVD risk in combination with statin treatment, its predicted effects on neurological/psychiatric traits may complicate its specificity. NEGRI (neuronal growth regulator-1) is expressed in the hypothalamus plays a role in energy balance and food intake 37,38 as well as being linked previously with major depressive disorder ${ }^{39}$. NEGR 1 was associated with fluid intelligence score in our analysis which may raise concerns about the wider neurological safety of targeting this pathway.

Our results also highlight promising genes which may potentially make worthwhile targets. For example, predicted SLC5A11 activation was highly associated with reduced risk of anthropometric (e.g. BMI) and cardiovascular traits but did not associate with any secondary potentially adverse effects in the PheWAS. SLC transporters are widely implicated in health and disease, and there is growing interest in strategies for therapeutic inhibition and activation of this protein family ${ }^{40}$. Similarly, drugs targeting the $P R K C E$ pathway may provide clinical benefit based on our analysis. PRKCE encodes PKC- $\varepsilon$, a member of the protein kinase $\mathrm{C}$ (PKC) serine/threonine protein kinases. The results of our PheWAS have predicted that PRKCE inhibition is not likely to elicit adverse secondary effects and may provide protection against high blood pressure. PKC- $\varepsilon$ is known to be expressed in the heart and may confer a cardioprotective role during ischemic heart failure ${ }^{41}$. Various in vitro and in vivo studies have provided evidence for a further role in mediating hypertrophy which may be dependent on PRKCE expression levels in the ischemic heart ${ }^{42}$.

\section{Limitations}


medRxiv preprint doi: https://doi.org/10.1101/2020.02.16.20023010; this version posted February 20, 2020. The copyright holder for this preprint (which was not certified by peer review) is the author/funder, who has granted medRxiv a license to display the preprint in It is made available under a CC-BY 4.0 International license .

The study has several methodological limitations. Firstly, genetically predicted molecular traits represent the cumulative effect of lifelong exposure on the outcome and therefore cannot be used to directly predict the short-term benefit of a putative drug ${ }^{43}$. Secondly, the CVD outcomes derived from field 20002 in the UKB cohort are based on selfreport. As such we firstly analyzed measured CVD risk factors from this cohort so that the risk of potential bias by implementing self-reported data from the population cohort is mitigated. Finally, our analysis is restricted to blood derived cis-eQTL due to availability of data, rendering them liable to loss of sensitivity to detect tissue-specific effects on disease susceptibility $^{44}$. For example, the results of our analysis suggest that PSRC1 expression at the 1p13.3 locus may associate with LDL cholesterol, although previous functional endeavors and those that using liver-derived expression data suggest that the likely causal gene for this signal is $\operatorname{SORT1} 1^{45,46}$.

\section{Conclusions}

The use of large-scale genetic studies employing Mendelian randomization can provide a cost-effective approach to accelerate the identification of viable drug targets to treat disease. Further pre-clinical studies are needed to validate the effectiveness of inhibiting targets which are prioritized by such efforts. 
medRxiv preprint doi: https://doi.org/10.1101/2020.02.16.20023010; this version posted February 20, 2020. The copyright holder for this preprint (which was not certified by peer review) is the author/funder, who has granted medRxiv a license to display the preprint in perpetuity.

It is made available under a CC-BY 4.0 International license .

\section{References}

1. Townsend N, Wilson L, Bhatnagar P, Wickramasinghe K, Rayner M, Nichols M. Cardiovascular disease in Europe: epidemiological 2016. European Heart Journal. 2016;27(42):3232-3245.

2. Kohli-Lynch CN, Bellows BK, Thanassoulis G, et al. Cost-effectiveness of Low-density Lipoprotein Cholesterol Level-Guided Statin Treatment in Patients With Borderline Cardiovascular Risk. JAMA Cardiol. 2019.

3. Ridker PM, Cook NR. Statins: new American guidelines for prevention of cardiovascular disease. Lancet. 2013;382(9907):1762-1765.

4. Law MR, Wald NJ, Rudnicka AR. Quantifying effect of statins on low density lipoprotein cholesterol, ischaemic heart disease, and stroke: systematic review and meta-analysis. Bmj. 2003;326(7404):1423.

5. Cholesterol Treatment Trialists C, Mihaylova B, Emberson J, et al. The effects of lowering LDL cholesterol with statin therapy in people at low risk of vascular disease: meta-analysis of individual data from 27 randomised trials. Lancet (London, England). 2012;380(9841):581590.

6. Swerdlow DI, Preiss D, Kuchenbaecker KB, et al. HMG-coenzyme A reductase inhibition, type 2 diabetes, and bodyweight: evidence from genetic analysis and randomised trials. Lancet. 2015;385(9965):351-361.

7. Sugiyama T, Tsugawa $\mathrm{Y}, \mathrm{Tseng} \mathrm{CH}$, Kobayashi $\mathrm{Y}$, Shapiro MF. Different time trends of caloric and fat intake between statin users and nonusers among US adults: gluttony in the time of statins? JAMA Intern Med. 2014;174(7):1038-1045.

8. Davidson MH. Squalene synthase inhibition: a novel target for the management of dyslipidemia. Curr Atheroscler Rep. 2007;9(1):78-80.

9. Akyea RK, Kai J, Qureshi N, lyen B, Weng SF. Sub-optimal cholesterol response to initiation of statins and future risk of cardiovascular disease. Heart. 2019:heartjnl-2018-314253.

10. Davey Smith G, Hemani G. Mendelian randomization: genetic anchors for causal inference in epidemiological studies. Hum Mol Genet. 2014;23(R1):R89-98.

11. Davey Smith G, Ebrahim S. 'Mendelian randomization': can genetic epidemiology contribute to understanding environmental determinants of disease?*. International Journal of Epidemiology. 2003;32(1):1-22.

12. Swanson SA, Tiemeier H, Ikram MA, Hernan MA. Nature as a Trialist?: Deconstructing the Analogy Between Mendelian Randomization and Randomized Trials. Epidemiology. 2017;28(5):653-659.

13. Chatterjee NA, Giulianini F, Geelhoed B, et al. Genetic Obesity and the Risk of Atrial Fibrillation: Causal Estimates from Mendelian Randomization. Circulation. 2017;135(8):741754.

14. Ference BA, Kastelein JJP, Ray KK, et al. Association of Triglyceride-Lowering LPL Variants and LDL-C-Lowering LDLR Variants With Risk of Coronary Heart Disease. JAMA. 2019;321(4):364373.

15. Burgess S, Ference BA, Staley JR, et al. Association of LPA Variants With Risk of Coronary Disease and the Implications for Lipoprotein(a)-Lowering Therapies: A Mendelian Randomization Analysis. JAMA Cardiol. 2018;3(7):619-627.

16. Ference BA, Majeed F, Penumetcha R, Flack JM, Brook RD. Effect of naturally random allocation to lower low-density lipoprotein cholesterol on the risk of coronary heart disease mediated by polymorphisms in NPC1L1, HMGCR, or both: a $2 \times 2$ factorial Mendelian randomization study. Journal of the American College of Cardiology. 2015;65(15):1552-1561.

17. Ference BA, Robinson JG, Brook RD, et al. Variation in PCSK9 and HMGCR and Risk of Cardiovascular Disease and Diabetes. N Engl J Med. 2016;375(22):2144-2153.

18. Bycroft C, Freeman C, Petkova D, et al. The UK Biobank resource with deep phenotyping and genomic data. Nature. 2018;562(7726):203-209. 
medRxiv preprint doi: https://doi.org/10.1101/2020.02.16.20023010; this version posted February 20, 2020. The copyright holder for this preprint (which was not certified by peer review) is the author/funder, who has granted medRxiv a license to display the preprint in perpetuity.

It is made available under a CC-BY 4.0 International license .

19. Võsa U, Claringbould A, Westra H-J, et al. Unraveling the polygenic architecture of complex traits using blood eQTL metaanalysis. bioRxiv. 2018:447367.

20. Abecasis GR, Auton A, Brooks LD, et al. An integrated map of genetic variation from 1,092 human genomes. Nature. 2012;491(7422):56-65.

21. Richardson TG, Harrison S, Hemani G, Davey Smith G. An atlas of polygenic risk score associations to highlight putative causal relationships across the human phenome. elife. 2019;8:e43657.

22. Lawlor DA. Commentary: Two-sample Mendelian randomization: opportunities and challenges. Int J Epidemiol. 2016;45(3):908-915.

23. Burgess S, Butterworth A, Thompson SG. Mendelian randomization analysis with multiple genetic variants using summarized data. Genet Epidemiol. 2013;37(7):658-665.

24. Hemani G, Zheng J, Elsworth B, et al. The MR-Base platform supports systematic causal inference across the human phenome. Elife. 2018;7.

25. Finan C, Gaulton A, Kruger FA, et al. The druggable genome and support for target identification and validation in drug development. Sci Trans/ Med. 2017;9(383).

26. Nelson MR, Tipney H, Painter JL, et al. The support of human genetic evidence for approved drug indications. Nature Genetics. 2015;47:856.

27. Santos R, Ursu O, Gaulton A, et al. A comprehensive map of molecular drug targets. Nature Reviews Drug Discovery. 2016;16:19.

28. Oprea TI, Bologa CG, Brunak S, et al. Unexplored therapeutic opportunities in the human genome. Nature Reviews Drug Discovery. 2018;17:317.

29. Lundbäck V, Kulyte A, Strawbridge RJ, et al. FAM13A and POM121C are candidate genes for fasting insulin: functional follow-up analysis of a genome-wide association study. Diabetologia. 2018;61(5):1112-1123.

30. Do R, Kiss RS, Gaudet D, Engert JC. Squalene synthase: a critical enzyme in the cholesterol biosynthesis pathway. Clin Genet. 2009;75(1):19-29.

31. Benichou C. Criteria of drug-induced liver disorders. Report of an international consensus meeting. J Hepatol. 1990;11(2):272-276.

32. Stein EA, Bays H, O'Brien D, Pedicano J, Piper E, Spezzi A. Lapaquistat acetate: development of a squalene synthase inhibitor for the treatment of hypercholesterolemia. Circulation. 2011;123(18):1974-1985.

33. Swerdlow DI, Preiss D, Kuchenbaecker KB, et al. HMG-coenzyme A reductase inhibition, type 2 diabetes, and bodyweight: evidence from genetic analysis and randomised trials. Lancet. 2015;385(9965):351-361.

34. Chong M, Sjaarda J, Pigeyre M, et al. Novel Drug Targets for Ischemic Stroke Identified Through Mendelian Randomization Analysis of the Blood Proteome. Circulation. 2019;140(10):819-830.

35. Kerr AG, Tam LCS, Hale AB, et al. A Genomic DNA Reporter Screen Identifies Squalene Synthase Inhibitors That Act Cooperatively with Statins to Upregulate the Low-Density Lipoprotein Receptor. Journal of Pharmacology and Experimental Therapeutics. 2017;361(3):417.

36. Elsayed RK, Evans JD. Emerging lipid-lowering drugs: squalene synthase inhibitors. Expert Opin Emerg Drugs. 2008;13(2):309-322.

37. Speliotes EK, Willer CJ, Berndt SI, et al. Association analyses of 249,796 individuals reveal 18 new loci associated with body mass index. Nat Genet. 2010;42(11):937-948.

38. Boender AJ, van Gestel MA, Garner KM, Luijendijk MC, Adan RA. The obesity-associated gene Negr1 regulates aspects of energy balance in rat hypothalamic areas. Physiol Rep. 2014;2(7).

39. Noh K, Lee H, Choi T-Y, et al. Negr1 controls adult hippocampal neurogenesis and affective behaviors. Molecular Psychiatry. 2019. 
medRxiv preprint doi: https://doi.org/10.1101/2020.02.16.20023010; this version posted February 20, 2020. The copyright holder for this preprint (which was not certified by peer review) is the author/funder, who has granted medRxiv a license to display the preprint in It is made available under a CC-BY 4.0 International license .

40. Lin L, Yee SW, Kim RB, Giacomini KM. SLC transporters as therapeutic targets: emerging opportunities. Nature Reviews Drug Discovery. 2015;14:543.

41. Churchill EN, Ferreira JC, Brum PC, Szweda LI, Mochly-Rosen D. Ischaemic preconditioning improves proteasomal activity and increases the degradation of deltaPKC during reperfusion. Cardiovasc Res. 2010;85(2):385-394.

42. Goldspink PH, Montgomery DE, Walker LA, et al. Protein kinase Cepsilon overexpression alters myofilament properties and composition during the progression of heart failure. Circ Res. 2004;95(4):424-432.

43. Labrecque JA, Swanson SA. Interpretation and Potential Biases of Mendelian Randomization Estimates With Time-Varying Exposures. Am J Epidemiol. 2019;188(1):231-238.

44. Richardson TG, Hemani G, Gaunt TR, Relton CL, Davey Smith G. A transcriptome-wide Mendelian randomization study to uncover tissue-dependent regulatory mechanisms across the human phenome. Nat Commun. 2020;11(1):185.

45. Taylor K, Davey Smith G, Relton CL, Gaunt TR, Richardson TG. Prioritizing putative influential genes in cardiovascular disease susceptibility by applying tissue-specific Mendelian randomization. Genome Med. 2019;11(1):6.

46. Musunuru K, Strong A, Frank-Kamenetsky M, et al. From noncoding variant to phenotype via SORT1 at the 1p13 cholesterol locus. Nature. 2010;466(7307):714-719. 
medRxiv preprint doi: https://doi.org/10.1101/2020.02.16.20023010; this version posted February 20, 2020. The copyright holder for this preprint (which was not certified by peer review) is the author/funder, who has granted medRxiv a license to display the preprint in It is made available under a CC-BY 4.0 International license.

\section{Acknowledgements}

We are immensely grateful to the participants of the UK Biobank study whose data were accessed under application 15825 in this study. We would also like to thank Benjamin Elsworth for making the summary statistics publicly available from genome-wide association studies of cardiovascular risk factors for the benefit of this research. Finally, we wish to thank the efforts of the Neale Lab who conducted extensive heritability analyses in the UK Biobank which guided our selection of traits to analyze in our phenome-wide association analyses.

\section{Ethical approval}

All individual participant data used in this study were obtained from the UK Biobank study who have obtained ethics approval from the Research Ethics Committee (REC - approval number: 11/NW/0382). All participants enrolled in UK Biobank have signed consent forms.

\section{Funding}

This work was supported by the Integrative Epidemiology Unit which receives funding from the UK Medical Research Council and the University of Bristol (MC_UU_00011/4). GML is supported by the British Heart Foundation (FS/17/60/33474). TGR is a UKRI Innovation Research Fellow (MR/S003886/1).

Disclosure: TRG receives research funding from GlaxoSmithKline and Biogen although neither company contributed to design or implementation of this study. 


\section{Figures and legends}

\section{Figure 1 - An illustration of the concept behind factorial Mendelian randomization}
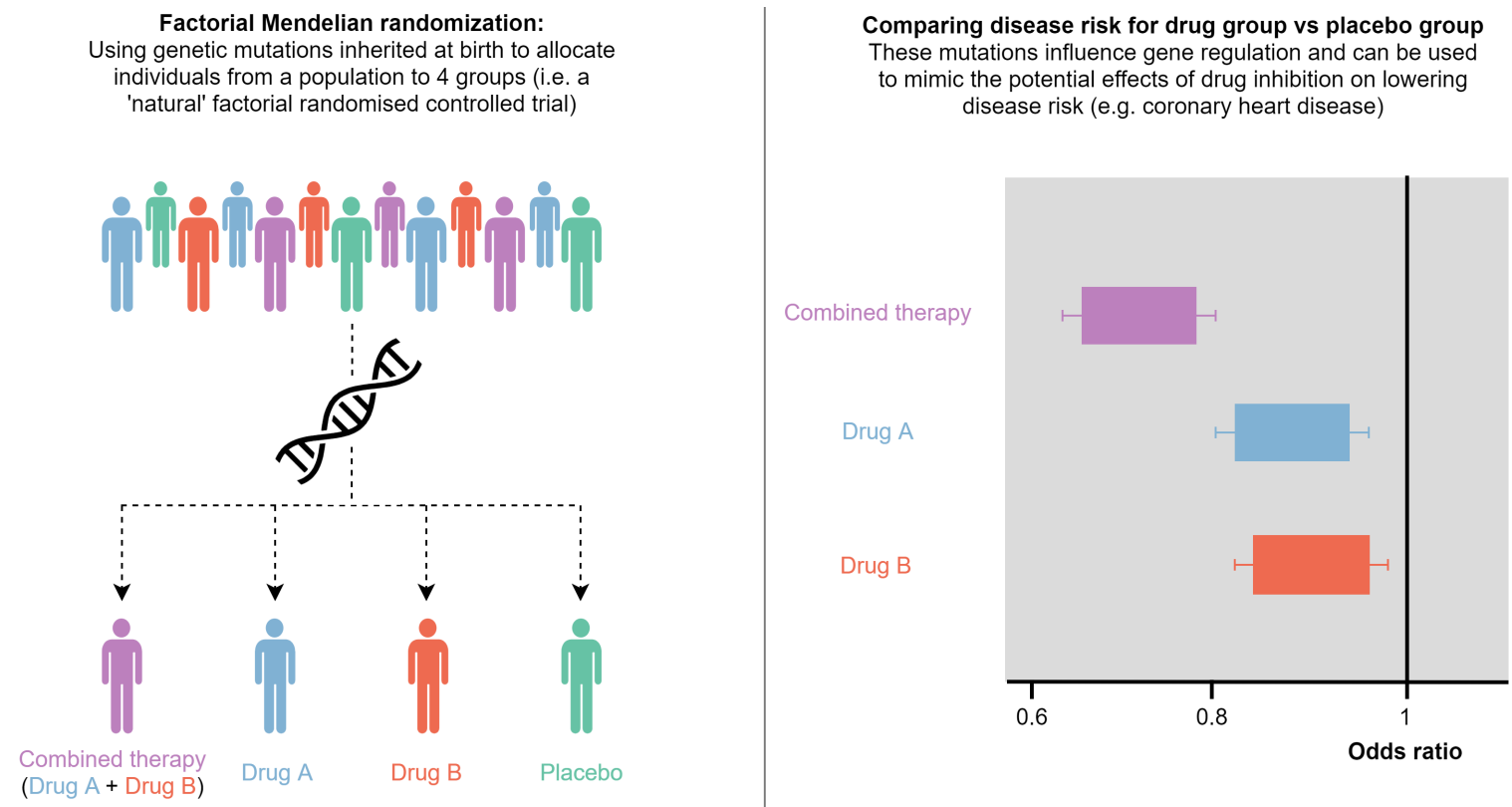

Using naturally occurring genetic mutations in a population, individuals are allocated to 4 different groups depending on whether they harbor mutations known to influence the regulation of two target genes. These mutations are combined into two scores, one for each gene, which can be used to mimic the potential impact of inhibiting their regulation. As such, people allocated to the placebo group have a score less than the median for both genes, Drug A/Drug B groups have a score higher than the median for one gene but not the other, whereas those in the combined therapy group have higher scores than the median for both genes.

By comparing incidence of disease in each group with the placebo group, it is possible to infer whether developing a drug for a novel gene target would yield an additive therapeutic benefit over current treatments. We have demonstrated this in our study to assess whether evaluating novel drug targets may be worthwhile in terms of treating coronary heart disease on top of $H M G C R$ inhibition (i.e. statin therapy). 
Figure 2 - Manhattan plots illustrating the associations between the expression of 8,851 genes and 5 known risk factors for cardiovascular disease
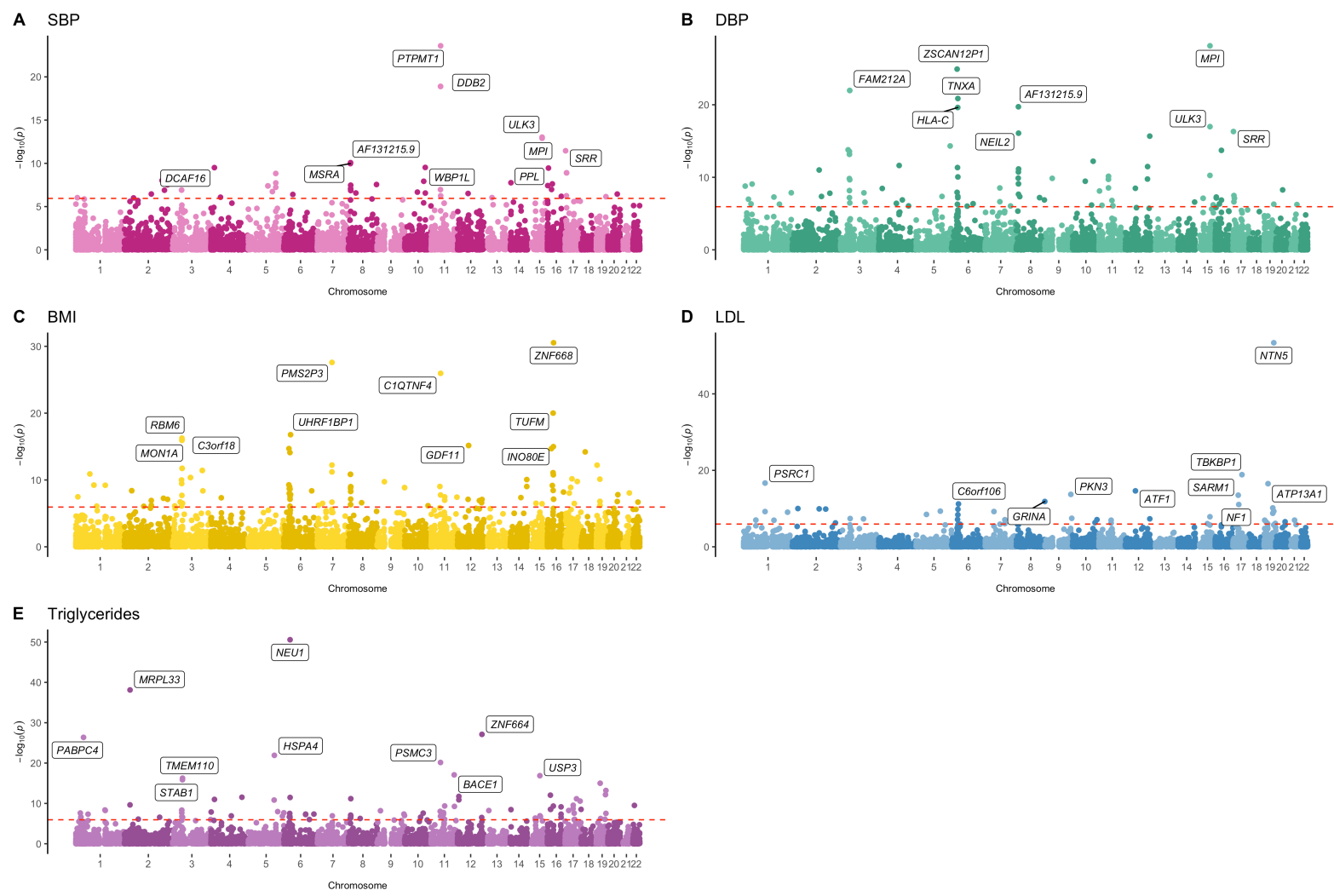

The y-axis indicates the $-\log ^{10} \mathrm{p}$-value for each genetically predicted effect with the corresponding gene's genomic location on the x-axis. Gene annotations refer to the top 10 predicted effects per trait. The horizontal dashed red line indicates the Bonferroni multiple testing threshold in this analysis (i.e. $\left.\mathrm{P}<0.05 /(8,851 * 5)=1.1298 \times 10^{-6}\right)$. Results for systolic blood pressure, diastolic blood pressure, body-mass index, LDL-cholesterol, and triglycerides are plotted on plots A-E respectively. 
medRxiv preprint doi: https://doi.org/10.1101/2020.02.16.20023010; this version posted February 20, 2020. The copyright holder for this preprint (which was not certified by peer review) is the author/funder, who has granted medRxiv a license to display the preprint in It is made available under a CC-BY 4.0 International license .

Figure 3 - Flow diagram of study analysis

\section{Analytical approach}

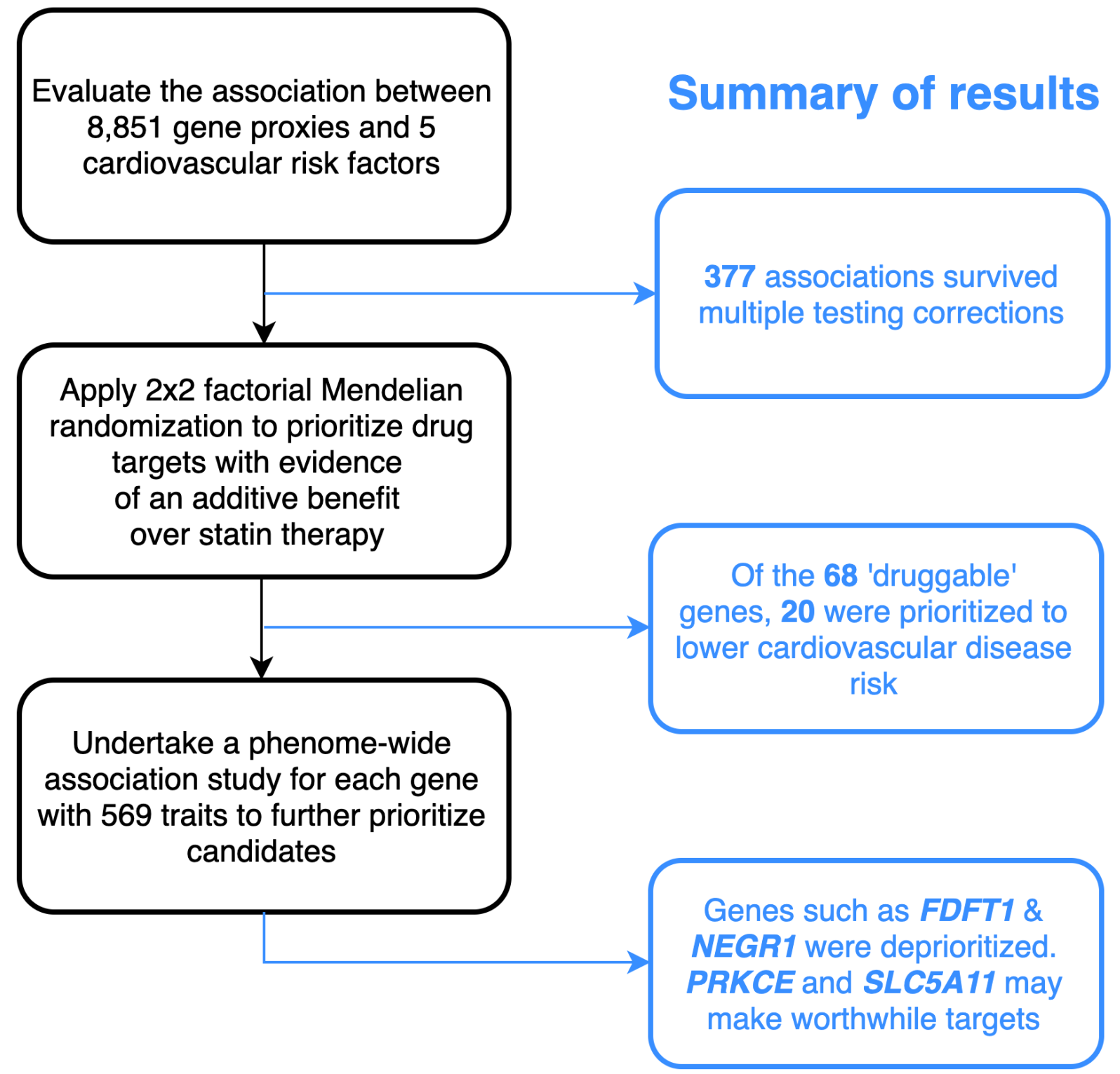

A flow diagram illustrating the different stages of this study and a summary of findings. 
medRxiv preprint doi: https://doi.org/10.1101/2020.02.16.20023010; this version posted February 20, 2020. The copyright holder for this preprint (which was not certified by peer review) is the author/funder, who has granted medRxiv a license to display the preprint in It is made available under a CC-BY 4.0 International license.

Figure 4 - A forest plot to illustrate 2x2 Factorial Mendelian Randomization estimates

\section{Gene Combinations}

\section{FDFT1}

HMGCR score above median

FDFT1 score above median

Both scores above median

NEGR1

HMGCR score above mediar

NEGR1 score above median

Both scores above median

\section{PRKCE}

HMGCR score above mediar

PRKCE score above median

Both scores above median

\section{SLC5A11}

HMGCR score above median SLC5A11 score above median

Both scores above median
Odds Ratio $[95 \% \mathrm{Cl}]$

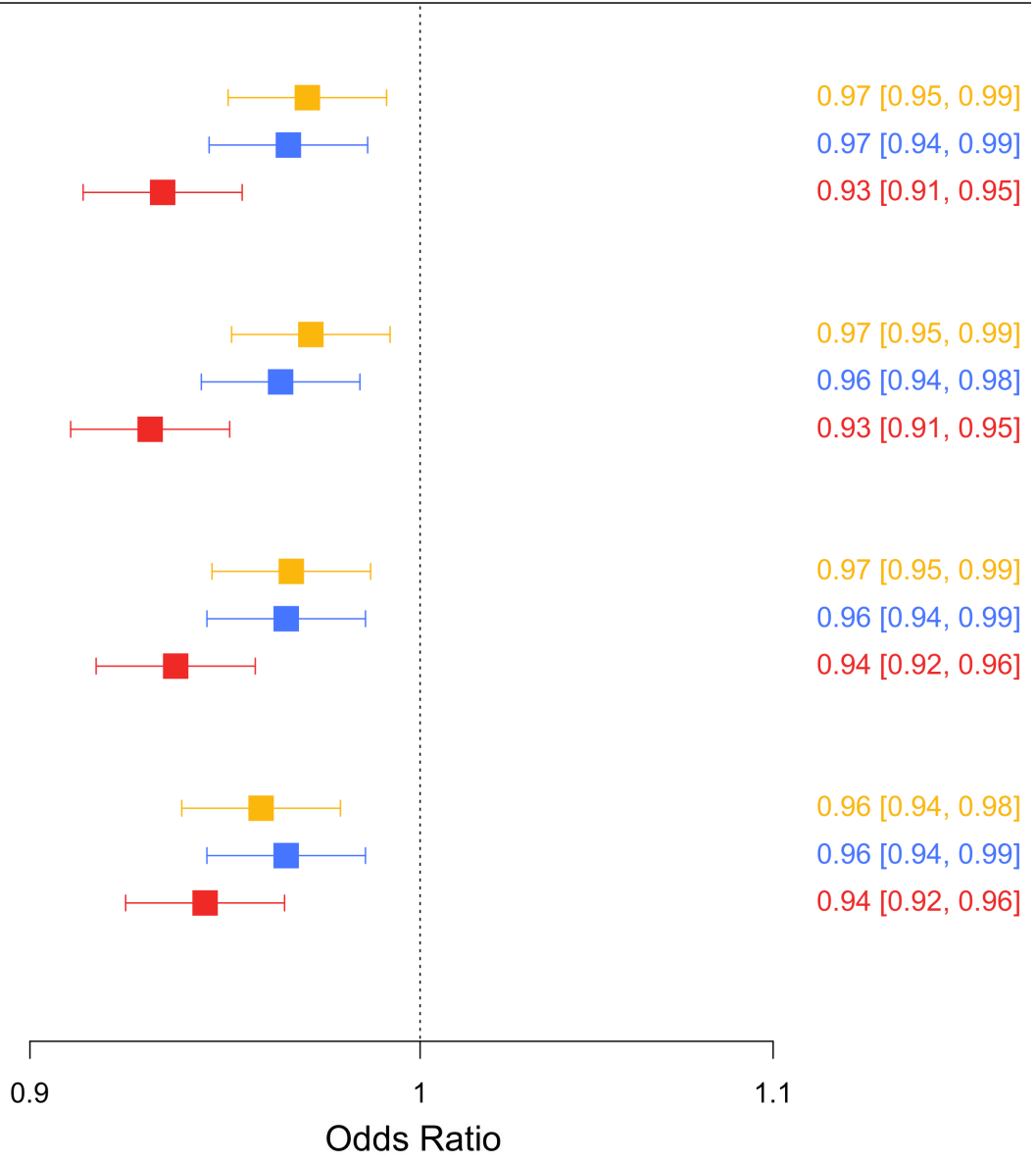

A comparison of findings from the $2 \times 2$ factorial Mendelian randomization analysis for 4 drug targets (FDFT1, NEGR1, PRKCE and SLC5A11). Genetic risk scores for each of these genes were constructed in the UK Biobank cohort and evaluated against a previously devised score for $H M G C R$ by Ference et al (2015). In turn, each score was compared with the HMGCR score to assess whether targeting them may lower cardiovascular disease risk in addition to statin therapy. 
medRxiv preprint doi: https://doi.org/10.1101/2020.02.16.20023010; this version posted February 20, 2020. The copyright holder for this preprint (which was not certified by peer review) is the author/funder, who has granted medRxiv a license to display the preprint in It is made available under a CC-BY 4.0 International license.

Figure 5 - Phenome-wide association plot for predicted genetic inhibition of (A)

\section{HMGCR, (B) FDFT1 and (C) PRKCE}

A

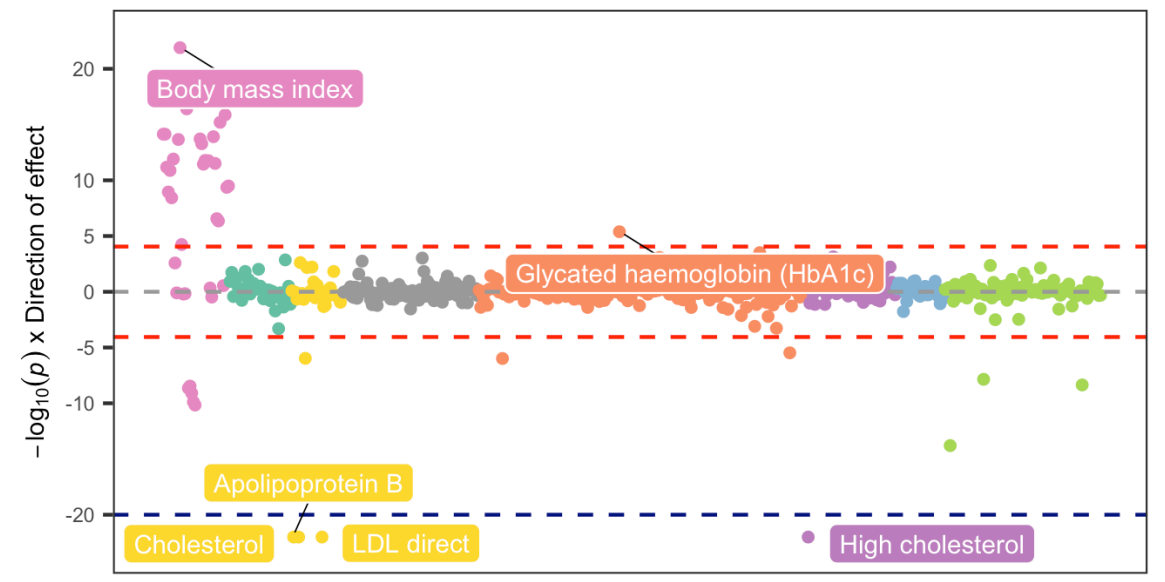

B

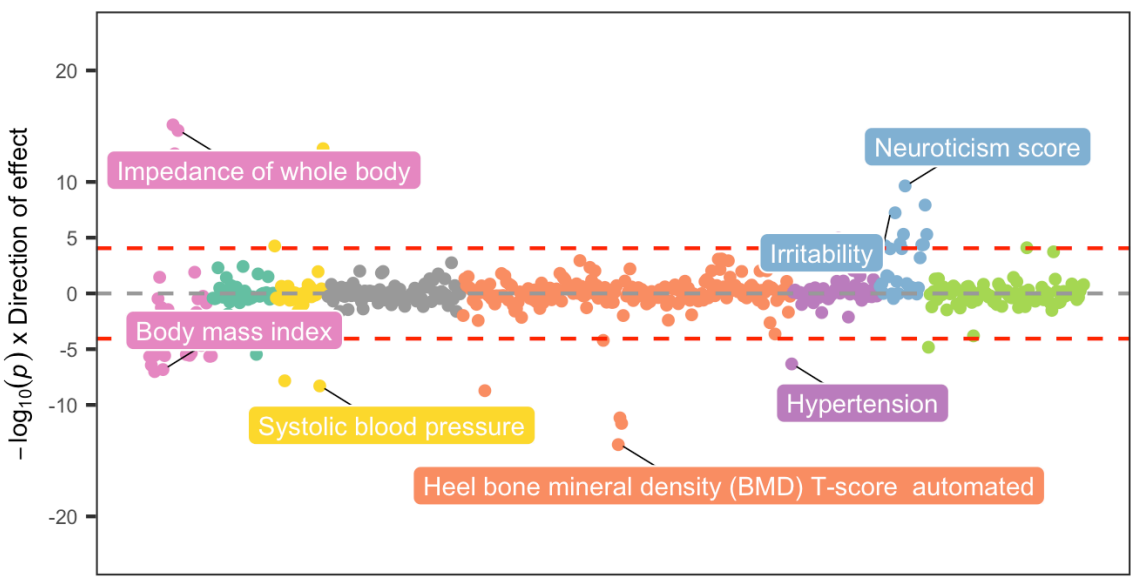

C

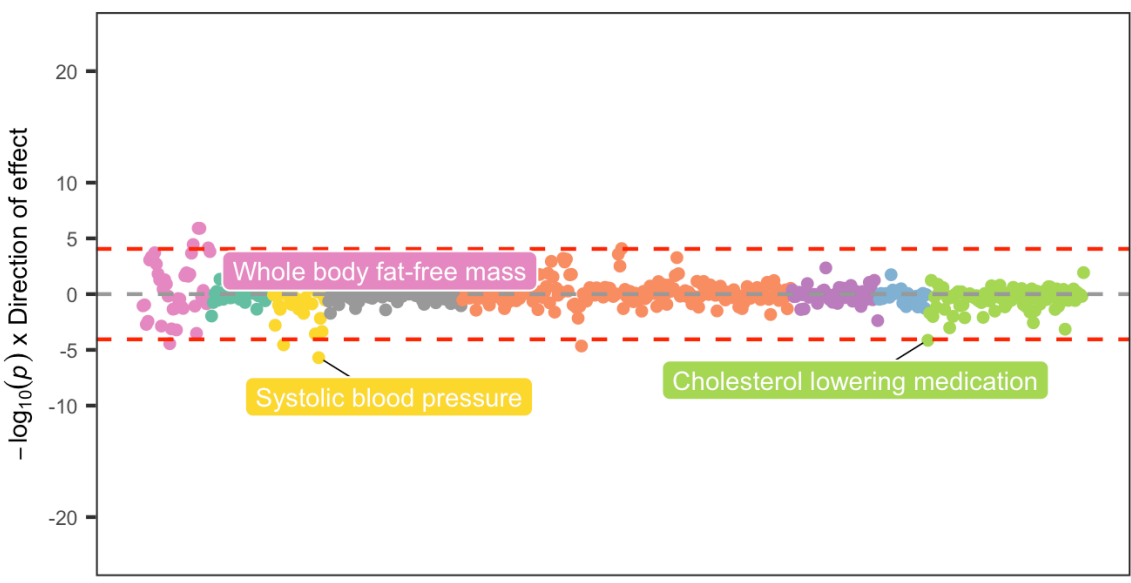

Subcategory

- Anthropometric

Behavioural

Cardiovascular

ICD10 codes

Miscellaneous

Non-cancer illness

- Psychiatric / neurological

Treatment/medication

\section{Subcategory}

- Anthropometric

- Behavioural

Cardiovascular

ICD10 codes

Miscellaneous

- Non-cancer illness

Psychiatric / neurological

Treatment/medication

\section{Subcategory}

- Anthropometric

- Behavioural

Cardiovascular

ICD10 codes

- Miscellaneous

- Non-cancer illness

- Psychiatric / neurological

Treatment/medication

Each point on the plot represents the association between the respective genetic score and a complex trait in UKB. The y-axis indicates the $-\log 10 \mathrm{p}$-value for each association after 
medRxiv preprint doi: https://doi.org/10.1101/2020.02.16.20023010; this version posted February 20, 2020. The copyright holder for this preprint (which was not certified by peer review) is the author/funder, who has granted medRxiv a license to display the preprint in It is made available under a CC-BY 4.0 International license.

orienting their direction of effect in line with predictive therapeutic inhibition (i.e. statins have an LDL cholesterol lowering effect and as such they reside below the null). Points are grouped and colored according to the corresponding subcategory for each trait. The horizontal dashed red line indicates the Bonferroni corrected threshold for 569 traits (i.e. $\mathrm{P}=-$ $\log 10\left(8.79 \times 10^{-5}\right)$ 
medRxiv preprint doi: https://doi.org/10.1101/2020.02.16.20023010; this version posted February 20, 2020. The copyright holder for this preprint (which was not certified by peer review) is the author/funder, who has granted medRxiv a license to display the preprint in It is made available under a CC-BY 4.0 International license.

\section{Supplementary figures}

\section{Supplementary Figure 1 - Phenome-wide association plot for predicted genetic} inhibition of NEGR1 (A) and SLC5A11 (B)

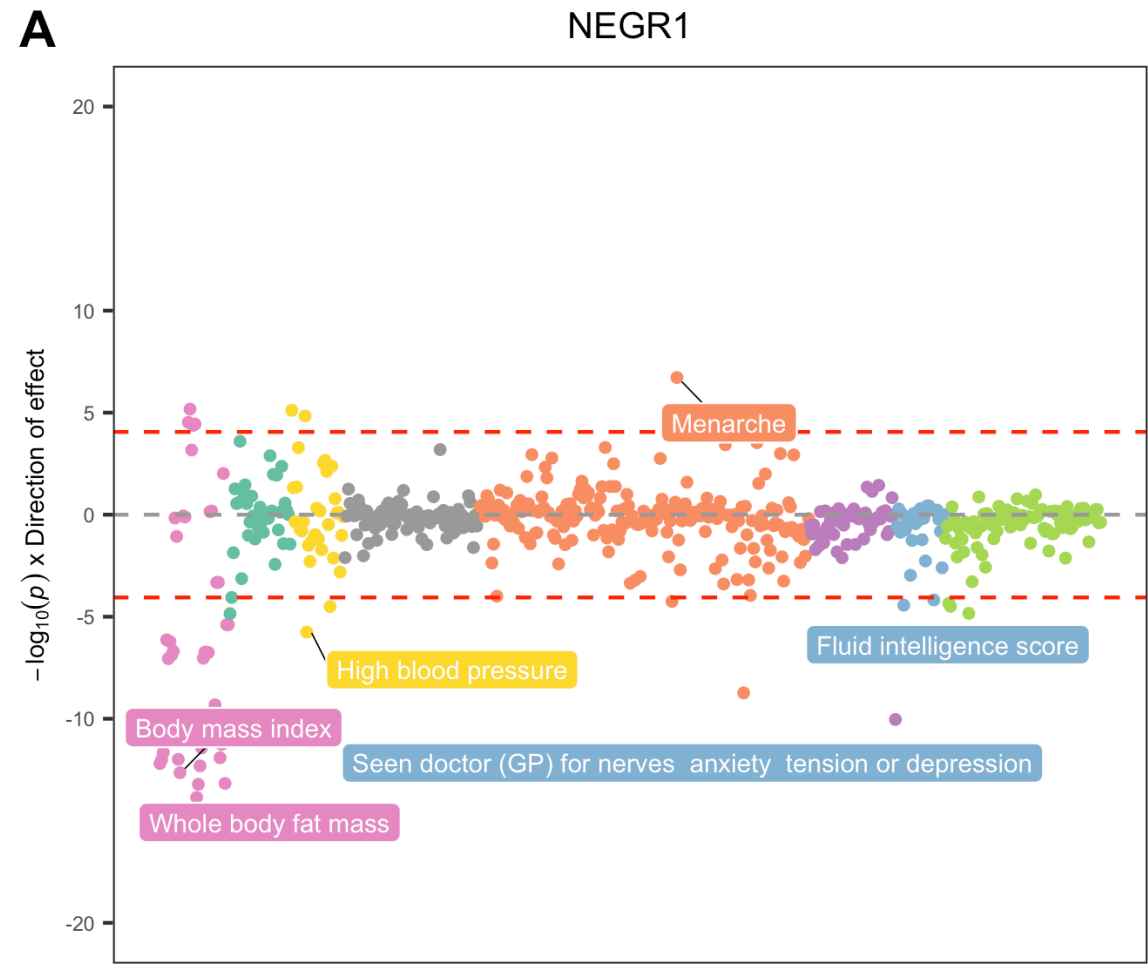

Subcategory

B

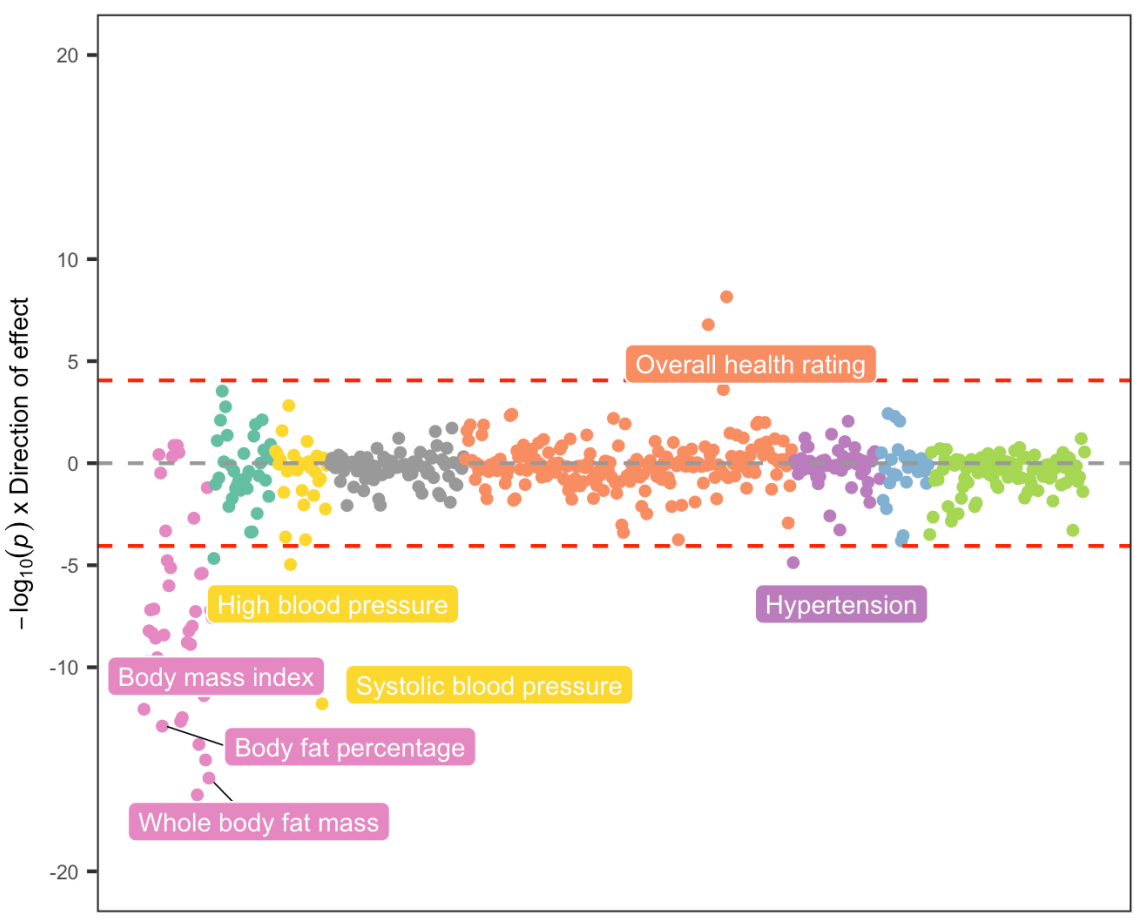

Anthropometric

- Behavioural

Cardiovascular

- ICD 10 codes

- Miscellaneous

Non-cancer illness

- Psychiatric / neurological

- Treatment/medication 
medRxiv preprint doi: https://doi.org/10.1101/2020.02.16.20023010; this version posted February 20, 2020. The copyright holder for this preprint (which was not certified by peer review) is the author/funder, who has granted medRxiv a license to display the preprint in It is made available under a CC-BY 4.0 International license .

Each point on the plot represents the association between the respective genetic score and a complex trait in UKB. The $y$-axis indicates the $-\log ^{10} \mathrm{p}$-value for the associations after orienting their direction of effect in line with predictive therapeutic treatment (i.e. statins have an LDL cholesterol lowering effect). Points are grouped and colored according to the corresponding subcategory for each trait. The horizontal dashed red line indicates the Bonferroni corrected threshold for multiple testing $\left(-\log 10(0.05 /(569))=-\log 10\left(8.79 \times 10^{-5}\right)\right.$. 